\title{
In Vitro Phytochemical Screening, Anti-Inflammatory and In Vivo Anti-Depressant, Anxiolytic Activities of Methanolic Extract of Leea aequata (leaves)
}

\author{
Joy Chowdhury ${ }^{1}$, Mohammad Jamshedur Rahman ${ }^{1}$, Shahriyer Mohammad Rafid ${ }^{1}$, Md. Mobarak \\ Hossain ${ }^{1}$, Mohammad Ali Shorab ${ }^{2}$, Mohammed Iqbal ${ }^{1}$ and Md. Shahidul Islam*1 \\ ${ }^{1}$ Department of Pharmacy, University of Science and Technology Chittagong, Bangladesh
}

${ }^{2}$ Department of Pharmacy, International Islamic University Chittagong, Bangladesh

*Corresponding author: Md. Shahidul Islam, Department of Pharmacy, University of Science and Technology Chittagong, Bangladesh

\begin{abstract}
ARTICLE INFO
Received: 幽 April 29, 2020

Published: 幽 June 15, 2020

Citation: Joy C, Mohammad Jamshedur R, Shahriyer Mohammad R, Md. Mobarak H, Md. Shahidul I. In Vitro Phytochemical Screening, Anti-Inflammatory and In Vivo Anti-Depressant, Anxiolytic Activities of Methanolic Extract of Leea aequata (leaves). Biomed J Sci \& Tech Res 28(2)2020. BJSTR. MS.ID.004626.
\end{abstract}

Keywords: Leea aequata; Anti-Inflammatory Effect; Anti-Depression and Anxiolytic

\section{ABSTRACT}

The core aim of the current research study was expose the in-vitro AntiInflammatory along with in-vivo Anxiolytic actions of methanolic extract of the Leea aequata Leaves under the family of Vitaceae. Leaves of the plant Leea aequata were collected from KEPZ Hill tract area, KEPZ, Chittagong, Bangladesh in the month of January 2018. This has been created that plants which also naturally synthesis as well as collect some of the secondary metabolites such as alkaloids, volatiles oils, glycosides, tannins, as well as contain minerals and also vitamins, have medicinal properties. Mainly phytochemical test of plant extract must be prepared for ensuring the existence of bioactive constituents of plant extract. This is primary phase of plant for work. Later than screening of phytochemicals of plants, it can presume the next phases what must to do with the plant extract. Here after screening of the Leea aequata it was observed positive results for the carbohydrates, Phytosterols, Flavonoids, Phenols, Tannins in addition to Saponins which must be good signs for advance research study with this plant. Here the plant Leea aequata having improved result on in vitro Anti-Inflammatory effect in Egg Albumin assessment. It has enhanced neuropharmacological value also. It also demonstrates superior effect on Anti-Depression in addition to anxiolytic

\section{Introduction}

The plant that have therapeutic actions or wield beneficial pharmacological outcomes on animal bodies are usually assigned as "Medicinal Plants". While there is no perceptible morphological property in medicinal plants producing with them, so far they have several special qualities that create them medicinally so important. Plant is someone of the huge number of life forms within biological kingdom of Plantae; generally, these classes are regarded as of partial motility as well as generally produce their individual food. They comprise a host of well-known organisms together with trees, grasses, forbs, shrubs, vines, ferns in addition to mosses [1]. Traditionally the word plant implies that a taxon with properties of multicellularity, cell structure along with walls holding cellulose in addition to organisms competent of photosynthesis [2]. The plant Leea aequata is usually used in tribes regions for Astringent,

Antipyretic, Anthelmintic, Alexiretic [3]. This is also helpful in Bronchitis, Dyspepsia, Anaesthesis of the skin, Bilious fever, Itching, Leprosy, Tuberculous and Ulcer. This is also recognized as a Kakjangha in the Bengali [4]. As it is known that inflammation is the complex method which is normally associated with the pain and involves incidences like the raise of the vascular permeability, raise of the protein denaturation in addition to membrane alteration [5]. Cells in body are harmed by microbes, chemical agents, physical agents, the damage is in form stress. Inflammation of the tissue is because of reply to stress [6]. Loss of task happens depends on site in addition to extent of the injury [7]. In view of the fact that inflammation is one of body's nonspecific inner systems of resistance, the reaction of the tissue to accidental hack is analogous to the reply that consequences from other sorts of tissue injure, reasoned by burns because of heat, radiation, viral or bacterial 
attack [8]. The duration of an nervous feeling can for a while be out of the proportion to original trigger, Physical symptoms like enlarged blood pressure in addition to nausea, can also happen to evident [9]. These answers move further than anxiety into anxiety disorder. So anxiety disorders happen when a result is out of the proportion to what might usually be supposed in a condition [10]. The main aim of the present research work was find out the Invitro Anti-Inflammatory and In-vivo Anxiolytic properties of the methanolic extract of Leea aequata Leaves (Figures 1 \& 2) \& (Tables $1 \& 2)$.

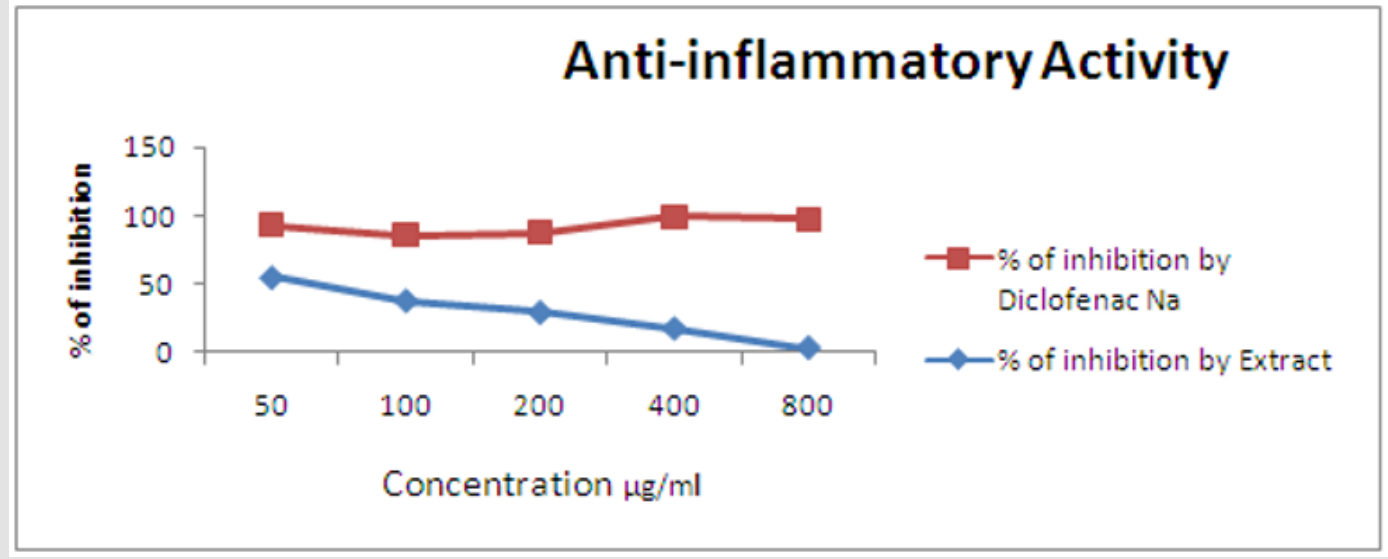

Figure 1: Percent of protein inhibition of Leea aequata with compare to standard Diclofenac Na.

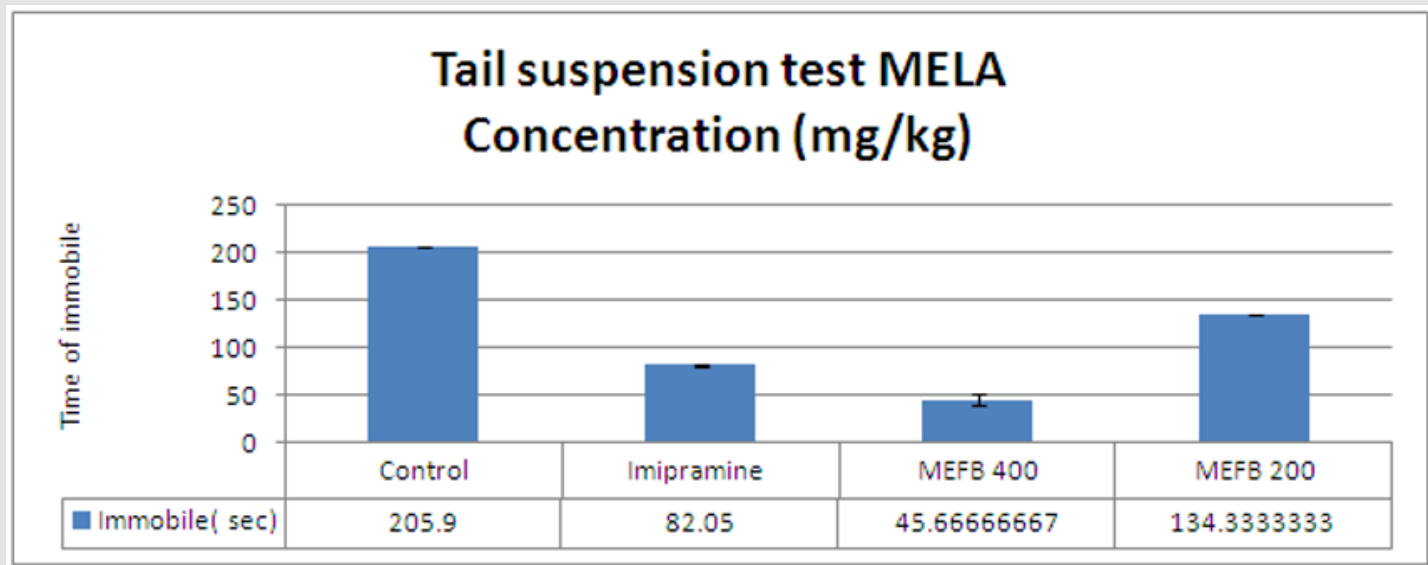

Figure 2: Effect of the Methanolic extract of Leea aequata on tail suspension test.

Table 1: Phytochemical Screening of Leea aequata.

\begin{tabular}{|c|c|c|c|}
\hline S. no. & \multicolumn{2}{|c|}{ Test Name } & Observation \\
\hline \multirow{3}{*}{1} & & Molish Test & ++ \\
\hline & Carbohydrate Test & Benedict Test & + \\
\hline & & Fehling A\&B & - \\
\hline \multirow{2}{*}{2} & & Mayer Test & + \\
\hline & Alkaloid Test & Wagners Test & + \\
\hline 3 & \multicolumn{2}{|c|}{ Glycosides Test } & - \\
\hline 4 & \multicolumn{2}{|c|}{ Phytosterol Test } & + \\
\hline 5 & \multicolumn{2}{|c|}{ Phenolic Test } & ++ \\
\hline 6 & \multicolumn{2}{|c|}{ Flavoniods Test } & ++ \\
\hline 7 & \multicolumn{2}{|c|}{ Protein Test } & - \\
\hline 8 & \multicolumn{2}{|c|}{ Saponins Test } & + \\
\hline 9 & \multicolumn{2}{|c|}{ Tannins test } & + \\
\hline
\end{tabular}

Note: showed in (Table-3).

$(+)=$ Present,$(++)=$ Rapidly present

$(-)=$ Absent. 
Table 2: Anti- inflammatory activity of Leea aequata.

\begin{tabular}{|c|c|c|c|c|c|}
\hline Sl. No. & Concentration $\mu \mathrm{g} / \mathrm{ml}$ & Test Control Abs. & Test Solution Abs. & $\begin{array}{c}\% \text { of Protein By } \\
\text { Extract }\end{array}$ & $\begin{array}{c}\% \text { of Protein By } \\
\text { Diclofenac }\end{array}$ \\
\hline 1 & 50 & 0.499 & 0.224 & 55.1 & 38 \\
\hline 2 & 100 & 0.499 & 0.309 & 38 & 47.5 \\
\hline 3 & 200 & 0.499 & 0.353 & 29.25 & 58.5 \\
\hline 4 & 400 & 0.499 & 0.412 & 17.43 & 82 \\
\hline 5 & 800 & 0.499 & 0.483 & 3.2 & 94 \\
\hline
\end{tabular}

\section{Materials and Methods}

\section{Animals}

Mice weighing about 28-32 gm aged about 1.5 month were purchased from animal house of Department of Pharmacy, Jahangirnagar University, Savar, Dhaka, Bangladesh. All the animals were acclimatized to new environment for a period of one week. During the test period the animals were kept in a well ventilated animal house at $25^{\circ} \mathrm{C}$. They were supplied with standard pellets and fresh drinking water. All the mice were kept in cage and maintained with natural $12 \mathrm{~h}$ light and dark cycle.

\section{In-vitro Anti-Anti-Inflammatory Activity of Leea Aequata}

\section{Egg Albumin Denaturation Method}

The anti-anti-inflammatory activity of methanolic extract of a plant was studied using the following procedure was followed by many authors [11] for evaluating the Percentage of inhibition of protein denaturation (Figure 1). The reaction combination was consisting of trial extract at unusual concentrations. $\mathrm{pH}$ of reaction combination was regulated using small quantity of $1 \mathrm{~N} \mathrm{HCl}$. The trials were hatched at the $37^{\circ} \mathrm{C}$ for $20 \mathrm{~min}$. in addition to heated for $5^{\circ} \mathrm{C}$ for $2 \mathrm{~min}$. Later than cooling the trials, turbidity was determined by spectrophotometrically at the $416 \mathrm{~nm}$ [12]. The test was done triplicate. The percentage (\%) inhibition of the protein denaturations were considered as follows:

$\%$ of Inhibition $=\left(\frac{A_{O}-A_{1}}{A_{O}}\right) \times 100$ Where,

$A_{0}=$ Absorbance of the control

$A_{1}=$ Absorbance of the sample

\section{Preparation of the Phosphate Buffer Saline $\left({ }_{p} H\right.$ 6.3)}

1. Transfer $8 \mathrm{~g}$ of $\mathrm{NaCl}, 0.2 \mathrm{~g}$ of $\mathrm{KCl}, 1.44 \mathrm{~g}$ of dipotassium hydrogen phosphate and 0.24 gram of the potassium dihydrogen phosphate to a one liter standard flask

2. Dissolve in $800 \mathrm{ml}$ of DW water.

3. Adjust the $\mathrm{PH}$ to 6.3 using $1 \mathrm{~N}$ Hydrochloric acid and framework the volume to $1000 \mathrm{ml}$ with the distilled water (DW).

\section{Preparation of Control Solution $(50 \mathrm{ml})$}

2 milliliter of egg albumin, 28 milliliter of phosphate buffer $(\mathrm{pH}$ 6.4 ) and $20 \mathrm{ml}$ distilled water. a. Preparation of Standard drug $(50 \mathrm{ml})$

b. It consists of $2 \mathrm{ml}$ of egg albumin, $28 \mathrm{ml}$ of phosphate buffer and various concentration of standard drug (Diclofenac $\mathrm{Na}$ ) concentration of 100, 200, 400 and $800 \mu \mathrm{g} / \mathrm{ml}$.

c. Preparation of test solution $(50 \mathrm{ml})$

d. It consists of $2 \mathrm{ml}$ of egg albumin, $28 \mathrm{ml}$ of phosphate buffer and various concentration of plant extract concentration of $100,200,400$ and $800 \mu \mathrm{g} / \mathrm{ml}$.

\section{Procedure}

$50 \mathrm{ml}$ various concentrations $(800,400,200,100 \mu \mathrm{g} / \mathrm{ml})$ of test solution and standard drug diclofenac sodium solution $(800,400,200,100 \mu \mathrm{g} / \mathrm{ml})$ were taken respectively.<smiles>[C]=C</smiles>

samples were keep warmed at $37^{\circ} \mathrm{Cfor} 20$ minutes<smiles>C=[Te]</smiles>

and heated at $70 \mathrm{o} \mathrm{C}$ for the five minutes.<smiles></smiles>

The absorbance was measured using UV-Visible spectrophotometer at $660 \mathrm{~nm}$.<smiles>[C]=C</smiles>

The control signifies $100 \%$ of the protein denaturation. The consequences were balanced with the diclofenac sodium. The percentage reticence of the protein denaturation can be computed as.

\section{In-Vivo Antidepressant Test}

Tail Suspension Test (TST): The end suspension technique used in study was analogous to those mentioned by some authors [4]. Treatment was provided $60 \mathrm{~min}$ prior to the study as mentioned by study design. Mice were shelved on edge of table, $50 \mathrm{~cm}$ higher than the floor, with help of the adhesive tape positioned around $1 \mathrm{~cm}$ from tip of tail. The total extent of immobility persuaded by end suspension was evidenced throughout $6 \mathrm{~min}$ of $10 \mathrm{~min}$ 
period. Animal was regarded as to be immobile at what time it did not confirm any progress of body, hanged inactively and entirely motionless [5].

Forced Swim Test (FST): For forced swim test (FST), mice of either gender were separately forced to the swim in open cylindrical pot it's is diameter $10 \mathrm{~cm}$, height $25 \mathrm{~cm}$ holding $19 \mathrm{~cm}$ of water at the $25 \pm 1^{\circ} \mathrm{C}$. Treatment was provided $60 \mathrm{~min}$ prior to the study as mentioned by the study design. Animals were forced to the swim for $7 \mathrm{~min}$ in addition to the extent of the immobility was monitored and determined during final $5 \mathrm{~min}$ interval of test. Here each mouse was the judged to be motionless when this ceased struggling in addition to remained floating immobile in water, making those associations to stay its head on top of water. A reduce in duration of quiet is pinpointing of the antidepressant effect (Table 3) [5].

Table 3: Effect of the Methanolic extract of Leea aequata on anti-depression test on tail suspension test in mice. Values are expressed as mean \pm S.E.M., $(n=6)$.

\begin{tabular}{|c|c|c|c|}
\hline Group & Treatment & Dose & Immobile time (s) \\
\hline control & $1 \%$ tween 80 solution & $10 \mathrm{ml} / \mathrm{kg}$, po & $205.90 \pm 0.00$ \\
\hline Standard & Imipramine & $10 \mathrm{mg} / \mathrm{kg}$, p & $82.05 \pm 0.00$ \\
\hline Test & MELA & $200 \mathrm{mg} / \mathrm{kg}$, po & 134.33 \\
\hline & MELA & $400 \mathrm{mg} / \mathrm{kg}$, po & 45.66 \\
\hline
\end{tabular}

MELA=Methanolic Extrac of Leea aequata.

In-vivo Anxiolytic Activity of Leea Aequata: Depending on mechanism, techniques for evaluation of the anti-inflammatory activity of samples can be determined by following two ways:

a. Hole board test

b. $\quad$ Elevated plus maze test

\section{Hole Board Test (HBT)}

Procedure: The method mentioned by some authors [4] was approved for testing the Central Nervous System (CNS) movement of the methanol fruits extract of the plant. The research study was performed using the wooden hole-board measuring 20 centimeter by $40 \mathrm{~cm}$ with 16 consistently spaced holes and each of diameter is $3 \mathrm{~cm}$. The equipment was raised to the height of 25 centimeter. 30 minutes later than treatment, mice were situated singly on center of board in addition to number head dipping as well as latency until first entrance was calculated using counter during the 5 min test period [4].

Elevated Plus Maze (EPM) Test Method: Animals were evaluated, numbered in addition to separated into five sets, each consisting 06 mice. One set was employed as control (like saline), second for typical drug (like diazepam) treatment of $3^{\text {rd }} 4^{\text {th }}$. As well as $5^{\text {th }}$ set for the coriandrum extract for the treatment (like Test $50 \mathrm{mg} / \mathrm{kg}, 100 \mathrm{mg} / \mathrm{kg}$ and $200 \mathrm{mg} / \mathrm{kg}$ ). Animals were positioned separately in center of maze, and head facing on the way to the open arm in addition to stopwatch was initiated. The following constraints were recorded for the $5 \mathrm{~min}$. First penchant of the mouse to the open or the closed arm. The number of accesses in the open arm. The average time of every animal uses in the open arm was estimated. Saline in addition to diazepam were inserted to control in addition to standard groups correspondingly. The coriandrum of extract was inserted to test groups. Later than 30 min and animals were situated separately in center of maze. Lastly, it was compared preference of animals to the open or the enclosed arm and average time used in the open arm.

\section{Results and Discussion}

\section{Phytochemical Screening}

The qualitative phytochemical screening was performed to ensure the presence or absence of secondary plant metabolites. In our investigation we have found positive results for carbohydrates, Alkaloids, Phytosterol, Phenol, Flavonoids, Tannins and Saponins. The result

showed in (Table 3).

$(+)=$ Present, $(++)=$ Rapidly present

$(-)=$ Absent.

\section{In-vitro Anti-inflammatory Activity}

The plant extract inhibited the protein denaturation by from a lowest $5 \%$ when conc. was $125 \mu \mathrm{g} / \mathrm{ml}$. To the highest \% of inhibition was $35 \%$ when concentration was $1000 \mu \mathrm{g} / \mathrm{ml}$ as compared to standard drug diclofenac Na inhibited by $82 \%$ at $1000 \mu \mathrm{g} / \mathrm{ml}$.

\section{Anti-Depressant Activity}

Test of Tail Suspension: Here test animals indulgenced with two doses of MELA 200 and $400 \mathrm{mg} / \mathrm{kg}$, Showed decreases in their serenity times and which was important $134.33 \pm 0.00$ and $45.66 \pm 0.00$ correspondingly when evaluated with the control (like $205.90 \pm 0.00$ ). Likewise, animals indulgenced with Imipramine (like $10 \mathrm{mg} / \mathrm{kg}$ ), as anticipated, showed a important decrease in immobility time (like $82.605 \pm 0.00$ ).

\section{Force Swim Test}

(Figure 3)The possible anti-depressant effect of MELA after oral administration was studied in the forced swimming test. In this trial animals indulgenced with two doses of MEBA 200 and $400 \mathrm{mg} / \mathrm{kg}$, showed decreases in their immobility times, which was significant 
$111.88 \pm 4.56 \mathrm{~s}$ and $84.88 \pm 3.61 \mathrm{~s}$ respectively, when compared with control $194.27 \pm 4.80$ s. Likewise, animals indulgenced with
Imipramine $10 \mathrm{mg} / \mathrm{kg}$, as anticipated, showed a important decrease in immobility time $88.66 \pm 2.93 \mathrm{~s}$.

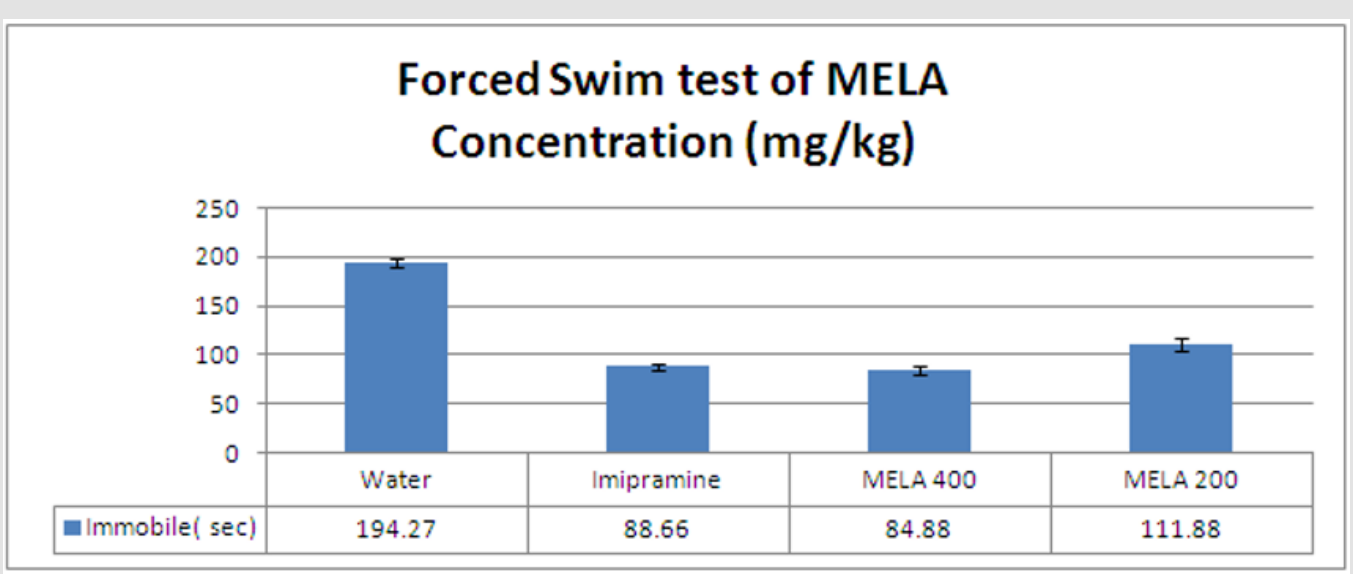

Figure 3: Effect of the Methanolic extract of Leea aequata on Force swim test.

\section{Anxiolytic Activities}

Hole Board: The possible Anxiolytic effect of MELA after oral administration was studied in the Hole board test (Figures 4 \& 5). In this trial animals indulgenced with two doses of MELA 200 and
$400 \mathrm{mg} / \mathrm{kg}$, showed increase in their number of head dipping, which was significant $33.66 \pm 0.00$ s and $45.33 \pm 0.00$ s respectively, when compared with control $26.33 \pm 0.00 \mathrm{~s}$. Similarly, animals treated with Diazepam $10 \mathrm{mg} / \mathrm{kg}$, as anticipated, showed a important increase in the No. of head dipping $88.66 \pm 0.00$ s.

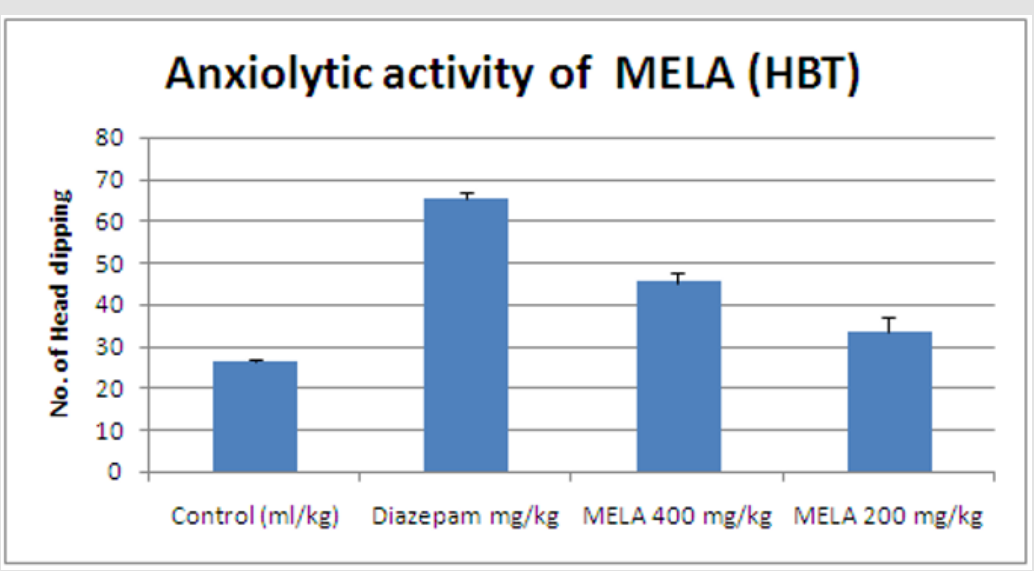

Figure 4: Effect of the Methanolic extract of Leea aequata on Force swim test.

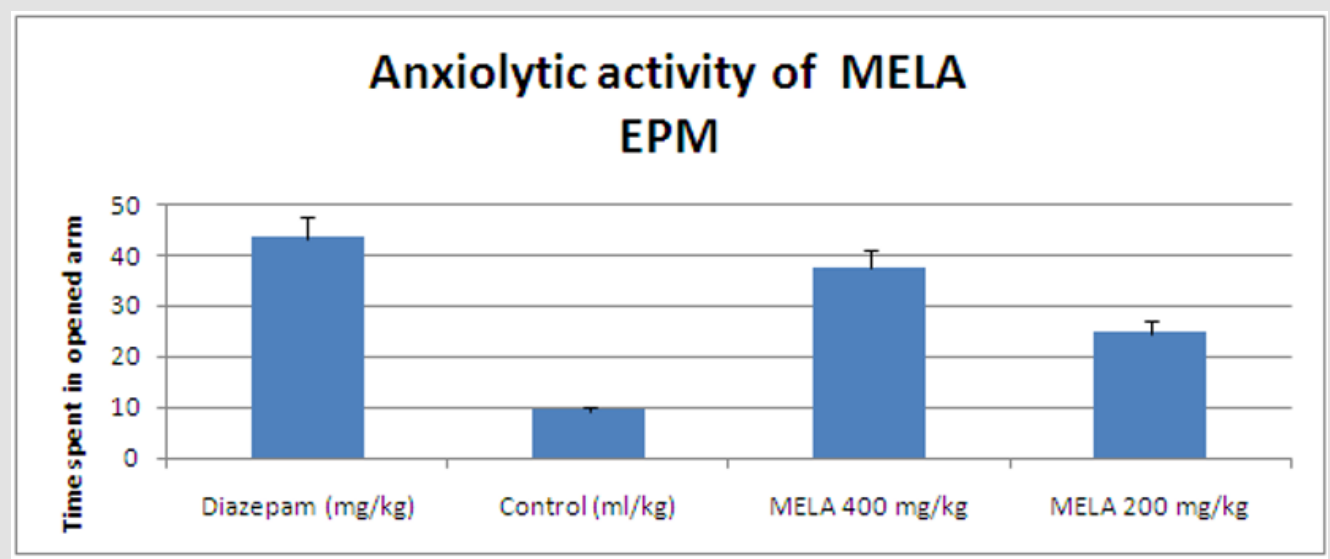

Figure 5: Effect of the Methanolic extract of Leea aequata on Elevated Plus Maze (EPM) test. 
Elevated Plus Maze (EPM): The possible Anxiolytic effect of MELA after oral administration was studied in the Elevated Plus Maze (EPM) test. In this test animals treated with two doses of MEBA 200 and $400 \mathrm{mg} / \mathrm{kg}$, showed in their time of Open arm, which was significant $24.66 \pm 0.00$ s and $37.33 \pm 0.00$ s respectively, when compared with control $9.36 \pm 0.00 \mathrm{~s}$. Similarly, animals treated with Diazepam $10 \mathrm{mg} / \mathrm{kg}$, as expected, showed a significant time of their close arm $43.33 \pm 0.00$ s.

\section{Conclusion}

In conclusion, this well-informed study evaluated significant phytochemical screening (Table 1) in-vitro Anti-Inflammatory and In-Vivo Anti-Depressant properties of the methanolic extract of Leea aequata at different doses (Tables 4-6). The plant contains a lot of major groups of organic compounds. According to study of the results and discussions of this plant extract it is prove that the plant may be a source of effective herbal drug. Although, All pharmacological profile were not performed for a single plant further improvements on such techniques and advancements in the procedure could be acquired through careful and systemic methods and hence requires advance new supplementary approaches. If possible more precise studies are needed to elucidate their mechanism of actions for individual photochemical.

Table 4: Effect of the Methanolic Extract of Leea aequata on anti depression test on force swim test in mice. Values are expressed as mean \pm S.E.M., $(n=6)$.

\begin{tabular}{|c|c|c|c|}
\hline Group & Treatment & Dose, rout & Immobility time (s) \\
\hline Control & Water & $10 \mathrm{ml} / \mathrm{kg}$, po & $194.27 \pm 4.80$ \\
\hline Standard & Imipramine & $10 \mathrm{mg} / \mathrm{kg}, \mathrm{ip}$ & $88.66 \pm 2.93$ \\
\hline Test & MELA & $200 \mathrm{mg} / \mathrm{kg}$, po & $111.88 \pm 4.56$ \\
\hline & MELA & $400 \mathrm{mg} / \mathrm{kg}$, po & $84.88 \pm 3.61$ \\
\hline
\end{tabular}

MELA=Methanolic Extract of Leea aequata.

Table 5: Effect of the Methanolic Extract of Leea aequata on anxiolytic test on Hole board test in mice. Values are expressed as mean \pm S.E.M, $(n=6)$.

\begin{tabular}{|c|c|c|c|}
\hline Group & Treatment & Dose, rout & Immobility time (s) \\
\hline Control & Water & $10 \mathrm{ml} / \mathrm{kg}$, po & $26.33 \pm 0.00$ \\
\hline Standard & Diazepam & $10 \mathrm{mg} / \mathrm{kg}, \mathrm{ip}$ & $65.55 \pm 0.00$ \\
\hline Test & MELA & $200 \mathrm{mg} / \mathrm{kg}$, po & $33.66 \pm 0.00$ \\
\hline & MELA & $400 \mathrm{mg} / \mathrm{kg}$, po & $45.33 \pm 0.00$ \\
\hline
\end{tabular}

MELA=Methanolic Extract of Leea aequata.

Table 6: Effect of the Methanolic Extract of Leea aequata on anxiolytic test on Elevated Plus Maze (EPM) test in mice. Values are expressed as mean \pm S.E.M, $(n=6)$.

\begin{tabular}{|c|c|c|c|}
\hline Group & Treatment & Dose, rout & Immobility time (s) \\
\hline Control & Saline $(\mathrm{NaCl})$ & $10 \mathrm{ml} / \mathrm{kg}$, po & $9.36 \pm 0.00$ \\
\hline Standard & Diazepam & $10 \mathrm{mg} / \mathrm{kg}$, ip & $43.33 \pm 0.00$ \\
\hline Test & MEBA & $200 \mathrm{mg} / \mathrm{kg}$, po & $24.66 \pm 0.00$ \\
\hline & MEBA & $400 \mathrm{mg} / \mathrm{kg}$, po & $37.33 \pm 0.00$ \\
\hline
\end{tabular}

MELA=Methanolic Extract of Leea aequata .

\section{References}

1. Ghani A (1998) Medicinal plants of Bangladesh: Chemical constituents and uses, Asiatic society of Bangladesh.

2. Rahman H, Eswaraiah MC, Dutta AM (2015) In-vitro anti-inflammatory and anti-arthritic activity of Oryza sativa var. joha rice (an aromatic indigenous rice of assam). American-Eurasian J Agric Environ Sci 15: 115-121.

3. Azwanida N (2015) A review on the extraction methods use in medicinal plants, principle, strength and limitation. Med Aromat Plants.

4. Sonavane G, Sarveiya V, Kasture V, Kasture S (2002) Anxiogenic activity of Myristica fragrans seeds. Pharmacology Biochemistry and Behavior 71: 239-244.

5. Dhingra D, Sharma A (2006) Antidepressant-like activity of Glycyrrhiza glabra L. in mouse models of immobility tests. Progress in NeuroPsychopharmacology and Biological Psychiatry 30: 449-454.

6. Abat JK, Kumar S, Mohanty A (2017) Ethnomedicinal, Phytochemical and Ethnopharmacological Aspects of Four Medicinal Plants of Malvaceae Used in Indian Traditional Medicines: A Review. Medicines (Basel) 4(4): 75.

7. Azam MN K, Ahmed MN, Rahman MM, Rahmatullah M (2013) Ethnomedicines used by the Oraon and Gor tribes of Sylhet district, Bangladesh. Am-Eur J Sustain Agr 7(5): 391-402.

8. El-Sherei MM, Ragheb AY, Kassem ME S, Marzouk MM, Mosharrafa SA, et al. (2016) Phytochemistry, biological activities and economical uses of the genus Sterculia and the related genera: A reveiw. Asian Pacific Journal of Tropical Disease 6(6): 492-501.

9. Govindarajan M (2010) Larvicidal and repellent activities of Sida acuta Burm. F.(Family: Malvaceae) against three important vector mosquitoes. Asian Pacific Journal of Tropical Medicine 3(9): 691-695.

10. Mobarakeh JI, Sakurada S, Katsuyama S, Kutsuwa M, Kuramasu A, et al. (2000) Role of histamine $\mathrm{H} 1$ receptor in pain perception: A study of the receptor gene knockout mice. European journal of pharmacology 391(1): 81-89.

11. Seyyed MS, Koochak H, Darabpour E, Motamedi H (2010) A survey on Hibiscus rosa-sinensis, Alcea rosea L. and Malva neglecta Wallr as antibacterial agents. Asian Pacific Journal of Tropical Medicine 3(5): 351-355.

12. Rahman AH MM, Gondha R (2014) Taxonomy and Traditional Medicine Practices on Malvaceae (Mallow Family) of Rajshahi, Bangladesh. Open Journal of Botany 1(2): 19-24. 
ISSN: 2574-1241

DOI: 10.26717/BJSTR.2020.28.004626

Md. Shahidul Islam. Biomed J Sci \& Tech Res

(C) (i) This work is licensed under Creative

Submission Link: https://biomedres.us/submit-manuscript.php

$\begin{array}{ll}\text { BIOMEDICAL } & \text { Assets of Publishing with us } \\ \text { RESEARCHES } & \text { - Global archiving of articles } \\ \text { - Immediate, unrestricted online access } & \text { - Rigorous Peer Review Process } \\ & \text { - Authors Retain Copyrights } \\ & \end{array}$

